\title{
Coronary stents seeded with human trophoblastic endovascular progenitor cells show accelerated strut coverage without excessive neointimal proliferation in a porcine model
}

\author{
Tushar Raina ${ }^{1}, \mathrm{MD}$, MRCP; Javaid Iqbal' ${ }^{1}$ MRCP, PhD; Nadine Arnold ${ }^{1}$, VN; Harry Moore 2 , BSc, PhD; \\ Behrouz Aflatoonian ${ }^{2}, \mathrm{BSc}, \mathrm{PhD}$; Jim Walsh ${ }^{3}$, BSc, PhD; Sam Whitehouse ${ }^{4}$, BSc, PhD; \\ Kadem Al-Lamee ${ }^{4}$, MSc, PhD; Sheila Francis ${ }^{1}$, BSc, PhD; Julian Gunn ${ }^{*}$, MD, MRCP \\ 1. Department of Cardiovascular Science, University of Sheffield, Sheffield, United Kingdom; 2. Centre for Stem Cell Biology, \\ University of Sheffield, Sheffield, United Kingdom; 3. Intercytex Ltd, Sheffield, United Kingdom; 4. Lombard Medical \\ Technologies PLC, Sheffield, United Kingdom
}

This paper also includes accompanying supplementary data published online at: http://www.pcronline.com/eurointervention/77th_issue/123

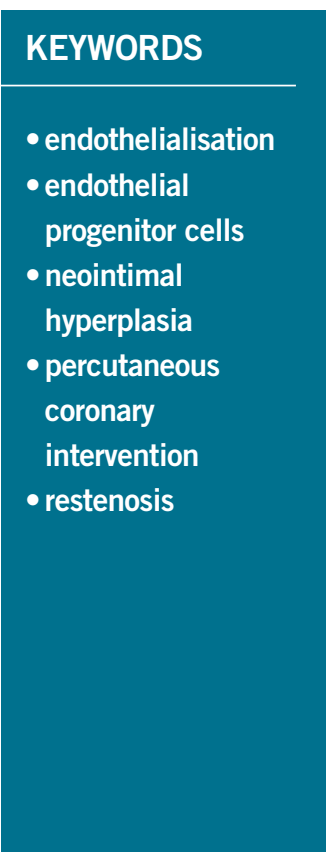

\section{Abstract}

Aims: The success of percutaneous coronary intervention (PCI) has been limited by restenosis and stent thrombosis. Delayed or incomplete endothelial regeneration is believed to be a key factor responsible for these events. Developing a stent with an accelerated healing profile may be of benefit. We aimed to evaluate the feasibility and safety of seeding a bare metal stent (BMS) with human trophoblastic endovascular progenitor cells (hTEC) derived from human embryonic stem cells.

Methods and results: A porcine coronary artery model was used to compare the rate and extent of endothelial regeneration and the degree of neointimal proliferation. Characterisation of hTEC confirmed a mixed progenitor and endothelial cell phenotype. The biodistribution and fate of hTEC were studied using radiolabelled ${ }^{111}$ Indium oxine and fluorescent in situ hybridisation. Scanning electron microscopy showed earlier endothelial coverage in hTEC-seeded stents as compared to similar BMS. hTEC-seeded BMS achieved complete stent coverage in three days. Quantitative coronary angiography, intravascular ultrasound assessment and histomorphometry showed no difference in neointimal hyperplasia between hTEC-seeded and control BMS.

Conclusions: hTEC seeding of coronary stents is a novel and safe approach to accelerate endothelial regeneration without increasing neointimal proliferation.

\footnotetext{
*Corresponding author: Department of Cardiovascular Science, University of Sheffield, Sheffield, S10 2RX, United Kingdom. E-mail:J.Gunn@sheffield.ac.uk
} 


\section{Abbreviations}

$\alpha$-SMA alpha smooth muscle actin

BMS bare metal stents

CD cluster of differentiation

Cpm counts per minute

DAPI 4',6 diamidino-2-phenylindole

DES drug-eluting stents

DMEM Dulbecco's modified eagle medium

EDTA ethylenediaminetetraacetic acid

EPC endothelial progenitor cells

FACS fluorescence activated cell sorting

FCS foetal calf serum

FISH fluorescent in situ hybridisation

FITC fluorescein isothiocyanate

HLA-G human leucocyte antigen-G

hTEC human trophoblastic endovascular progenitor cell

IVUS intravascular ultrasound

LAD left anterior descending artery

LLL late lumen loss

MLA minimal lumen area

MLD minimal lumen diameter

MSA minimal stent area

PBMC peripheral blood mononuclear cells

PAOEC porcine aortic endothelial cell

$\mathrm{PCI}$ percutaneous coronary intervention

QCA quantitative coronary angiography

RCA right coronary artery

SM-MHC smooth muscle myosin heavy chain

VEGF vascular endothelial growth factor

vWF von Willebrand factor

\section{Introduction}

Percutaneous coronary intervention (PCI) with angioplasty and stenting is the mainstay in the treatment of significant and symptomatic coronary artery disease ${ }^{1,2}$. Neointimal hyperplasia within bare metal stents (BMS), leading to in-stent restenosis, has been a longstanding limitation of $\mathrm{PCI}^{3}$. Drug-eluting stents (DES) have significantly reduced in-stent restenosis and the need for repeat $\mathrm{PCI}^{4,5}$. There are, however, concerns regarding the safety of DES, notably related to late stent thrombosis ${ }^{6-8}$, which is associated with adverse clinical outcomes and a mortality rate of $17-45 \% \%^{9,10}$.

Delayed or incomplete endothelial regeneration is one of the key factors responsible for late stent thrombosis. The therapeutic agents incorporated in DES are antiproliferative, and therefore inhibit healing and prevent or delay endothelial regeneration ${ }^{11}$. Autopsy studies of DES-treated arteries have revealed incomplete endothelialisation of stent struts with adherent platelets and inflammatory cells ${ }^{12,13}$. Post mortem examination of coronary segments from patients who underwent DES and BMS implantation has revealed delayed arterial healing and incomplete endothelialisation after DES implantation as compared to BMS implantation of similar duration ${ }^{12,13}$.

The newer generation of DES with biocompatible or biodegradable polymers, bioresorbable scaffolds and potent antiplatelet agents have reduced but not eliminated the risk of stent thrombosis. The development of stents bearing pro-healing agents is, therefore, of clinical interest, but has gained limited success to date. An endothelial progenitor cell (EPC) capture stent was safe and effective in initial studies ${ }^{14}$, but larger observational studies and randomised clinical trials revealed an excess of restenosis ${ }^{15-18}$. An alternative approach is to use stents already coated with progenitor cells. We have previously derived an enriched endovascular cell phenotype from cytotrophoblastic stem cell lines generated from human embryonic stem cells ${ }^{19}$. These human trophoblastic endovascular cells (hTEC) express human leucocyte antigen-G (HLA-G), potentially endowing them with immune-tolerance properties. The hTEC also exhibit distinct morphological and immunological similarities to cells of an endothelial progenitor phenotype ${ }^{20}$. We surmised that the pseudo-endothelial vasculogenic and invasive characteristics might make these cells applicable for seeding a stent.

We hypothesised that a cell-based regenerative strategy using hTEC seeding would accelerate endothelial regeneration without increasing neointimal hyperplasia after stent implantation in a porcine model of coronary stenting.

\section{Methods}

All animal work was carried out under UK Home Office licence in accordance with the Animals (Scientific Procedures) Act, 1986, and conforms with the Guide for the Care and Use of Laboratory Animals published by the US National Institutes of Health.

\section{CULTURE, PREPARATION AND CHARACTERISATION OF hTEC STEM CELLS}

hTEC were derived by the terminal differentiation of trophoblast stem cells while the latter were derived as distinct trophoblast cell lines from human embryonic stem cells (Shef 3 and six cell lines) $)^{21}$ and maintained in culture, using previously described protocols ${ }^{19,20}$ (Online Appendix). Immunological characterisation of hTEC was carried out by staining for endothelial progenitor markers: CD133, CD34 and vascular endothelial growth factor receptor-2 (VEGFR2) and mature endothelial markers; CD31, E-selectin and von Willebrand factor (vWF). hTEC were also stained for alpha smooth muscle actin (a-SMA) and smooth muscle myosin heavy chain (SM-MHC).

We then aimed to demonstrate that hTEC could survive in coculture with porcine endothelial and smooth muscle cells, isolated from porcine thoracic aortae (Online Appendix).

\section{CELL SEEDING OF STENTS}

hTEC were recovered from the culture flask by incubation in a solution of $0.25 \%$ trypsin and $0.02 \%$ ethylenediaminetetraacetic acid (EDTA). After five minutes digestion was stopped with Dulbecco's Modified Eagle Medium (DMEM) supplemented with 10\% foetal calf serum (FCS) and the cells washed by centrifugation $(\times 3)$ and counted (Neubauer counting chamber). Under a laminar flow hood and strict asepsis, BMS (Invastent Volo ${ }^{\circledR}$ Invatec S.p.A., Roncadelle, Italy) pre-mounted on a balloon catheter were inserted 
into sterile Nunc ${ }^{\circledR}$ CryoTubes (Sigma-Aldrich, Dorset, UK), seeded with $1 \times 10^{6}$ hTEC and maintained in standard cell culture conditions for three days with gentle agitation using a rocker tray (IKA ${ }^{\circledR}$ MTS-4; IKA ${ }^{\circledR}$-Werke GmbH \& Co, Staufen, Germany). For each batch of stents cultured with hTEC, two were fixed and processed for scanning electron microscopy for estimation of cell adherence and coverage.

\section{IMMUNOLOGICAL ISSUES}

Our experiments involved inserting a human stem cell-coated stent into a pig, so it was important to demonstrate any immunological ill-effects. The effect of any pre-existing circulating antihuman porcine antibodies upon hTEC was determined by exposing hTEC to porcine serum followed by flow cytometry analysis with fluorescein isothiocyanate (FITC) labelled anti-porcine IgG and IgM antibodies (Online Appendix).

\section{BIODISTRIBUTION AND LATE FATE OF hTEC}

Initial porcine experiments were focused on assessing whether the hTEC remained on the stent. BMS were seeded with hTEC, which had been radiolabelled with ${ }^{111}$ Indium oxine and maintained in cell culture conditions for three days. Stents were implanted in the left anterior descending (LAD) coronary artery of three Yorkshire White pigs, which were sacrificed at one hour, one day and seven days. The radioactivity over the stented segment of the explanted LAD and other organs was measured using a gamma counter. In addition, BMS seeded with hTEC derived from a male cell line (XY) were implanted in female pigs (XX). hTEC-seeded stents were implanted in the LAD or right coronary artery (RCA) and a BMS without seeded cells deployed in the contralateral artery for comparison. The animals were sacrificed at 28 days. Fluorescent human $\mathrm{X}, \mathrm{Y}$ and 18 chromosome probes were used to detect the human or pig origin of cells within the neointima. The stented vessels were dissected, fixed and cut longitudinally using tungsten scissors and opened en face. Tissue lining the inner surface of the stent halves (neointima) was removed, embedded and cut into sections. Paraffin sections from the neointimal tissue within the implanted BMS in the contralateral coronary artery were used as negative control and actively proliferating early passage hTEC used as positive controls. Fluorescent in situ hybridisation (FISH) analysis was performed using centromere specific chromosome $\mathrm{X}, \mathrm{Y}$ and 18 . The samples were counterstained with 4',6 diamidino-2-phenylindole (DAPI) and the images captured with a fluorescence microscope.

\section{STENT IMPLANTATION}

Normolipaemic, genetically normal, juvenile Yorkshire White pigs (20-30 kg) of either sex were anaesthetised and vascular access obtained through the right carotid artery. The stents used in this study (both for coating and for control groups) were $3.5 \times 11 \mathrm{~mm}$ Invastent $\mathrm{Volo}^{\circledR}$ pre-mounted on a rapid-exchange balloon stent delivery system. Invastent Volo ${ }^{\circledR}$ is a slotted-tube, closed cell design stent made up of stainless steel (316L) with a metallic surface area of $13.3 \%$ and strut thickness of $95 \mu \mathrm{m}$. The coronary arteries were intubated using standard guide catheters. Stent implantation sites were chosen to achieve a stent:artery ratio of 1.25:1 in suitable segments of LAD and RCA. The animals received $150 \mathrm{mg}$ aspirin and $75 \mathrm{mg}$ clopidogrel throughout the experiment.

\section{ASSESSMENT OF ENDOTHELIAL REGENERATION}

For endothelial regeneration experiments, eight animals received two stents each: hTEC-seeded $3.5 \times 11 \mathrm{~mm}$ BMS and uncoated identical BMS in the LAD or the RCA in alternating sequence. A coronary angiogram was performed at the end of each procedure to document arterial patency. The animals were sacrificed at one hour, one day, three days and seven days; the hearts were explanted and the stented arterial segments examined for stent strut coverage using a scanning electron microscope. Each stented vessel segment was cut longitudinally using tungsten scissors with the stent in situ and opened en face. After fixation and dehydration, samples were examined under a scanning electron microscope (Philips XL-20). Stent strut coverage was quantified in each stented vessel half. Images acquired under low magnification $(\times 25)$ were divided into four quadrants. Stent strut coverage was quantified under high magnification $(\times 100)$ in all four quadrants for the four samples for each time point. Each quadrant was assigned a strut coverage score from 1 to 4 according to the percentage covered struts: $1=(0-25 \%)$, $2=(25-50 \%), 3=(50-75 \%)$ and $4=(75-100 \%)$. The mean of the strut coverage scores for the four individual quadrants was taken as the strut coverage score for each sample.

\section{ASSESSMENT OF NEOINTIMAL GROWTH}

For neointimal proliferation experiments, 10 animals received two stents each, using the protocol described above. They underwent repeat coronary angiography and an intravascular ultrasound (IVUS) study at 28 days. QCA measurements were performed using the automated edge-detection algorithms of CAAS-5 software (Pie Medical, Maastricht, The Netherlands) by two independent experienced observers blinded to the treatment groups. The artery and stent diameters were measured at baseline and at 28 days. Minimal lumen diameter (MLD) was measured after stent implantation and at 28 days. Late lumen loss (LLL) was calculated as the difference between the MLD at 28 days and the MLD after stent implantation.

The IVUS imaging runs were acquired from $5 \mathrm{~mm}$ distal from the stented segment to $5 \mathrm{~mm}$ proximal to the stented segment at a constant pullback speed of $1 \mathrm{~mm} / \mathrm{sec}$. Still image frames were analysed using the contour detection software supplied with the imaging system. The minimal stent area (MSA) and minimal lumen area (MLA) were calculated. The minimal lumen diameter (MLD) was derived assuming a circular model and using the formula: $\mathrm{MLD}=2 \times \sqrt{\mathrm{MLA} / \pi}$. The hearts were explanted and the stented arterial segments fixed, embedded and serially sectioned into $20-30 \mu \mathrm{m}$ thick sections, as previously described ${ }^{22}$. Stented sections were examined microscopically and images captured using a high-resolution digital camera with output to a computerised image analysis system (NIS-Elements software; Nikon, Kingston upon Thames, UK). For each section, the vessel area, lumen area, neointimal 
area and the mean injury score were measured. The arterial injury caused by the stent overstretch was quantified using Schwartz ${ }^{23}$. The mean of the individual stent strut injury scores was taken as the injury score for each section.

\section{Statistical analysis}

Data are expressed as mean \pm SEM. Comparisons between groups were made using two-tailed Student's t-tests. A probability of $\mathrm{p}<0.05$ was considered statistically significant. Statistical analyses were performed using GraphPad Prism ${ }^{\circledR}$ software version 5.02 (GraphPad Software, San Diego, CA, USA).

\section{Results}

\section{PREPARATION OF STEM CELLS (hTEC)}

hTEC demonstrated a mixed progenitor and mature endothelial phenotype, expressing both progenitor (CD133 and VEGFR-2) and mature endothelial (CD31, E-selectin and vWF) markers. These cells survived in co-culture with porcine endothelial (PAoEC) and vascular smooth muscle cells (VSMC). Only $2.0 \%$ of hTEC showed any binding to porcine anti-porcine IgG or IgM antibodies as compared to $12-15 \%$ of porcine peripheral blood mononuclear cells (PBMC) (Figure 1).

\section{BIODISTRIBUTION AND FATE OF hTEC AFTER STENT IMPLANTATION}

For the stents seeded with ${ }^{111}$ Indium-labelled hTEC, the radioactivity measured over the explanted stented LAD was 77,642 cpm at one hour, 20,048 cpm at one day and 2,323 cpm at seven days, with no significant radioactivity detected at any of the distal sites, including blood vessels, heart, lung, spleen, liver and kidneys. Neointimal tissue obtained from within the hTEC (XY) seeded stents implanted in the female pigs $(\mathrm{XX})$ did not show any fluorescent signal when human probes specific for $\mathrm{X}, \mathrm{Y}$ and 18 chromosomes were applied (Figure 2). No fluorescence was seen in the paraffin sections of the neointimal tissue obtained from within the BMS implanted in the contralateral coronary artery. By comparison, FISH of early passage hTEC showed a fluorescent signal for all three probes (Figure 2).

\section{hTEC ACCELERATES STRUT COVERAGE}

Scanning electron microscopy of the hTEC-seeded stent group showed an increased coverage of cells as compared to the BMS controls, at all early time points, the difference being most marked at one hour (Figure 3). At day three, the hTEC-seeded stents were completely covered by a layer of tissue whereas the BMS struts could still be seen. At day seven, both groups were well covered with tissue (Figure 3). Quantification of stent strut coverage revealed a significantly accelerated tissue coverage in hTEC-seeded stents (Figure 4).

\section{hTEC DO NOT INCREASE NEOINTIMAL PROLIFERATION}

Angiographic assessment with QCA did not show any significant difference in minimal lumen diameter at baseline, post stent
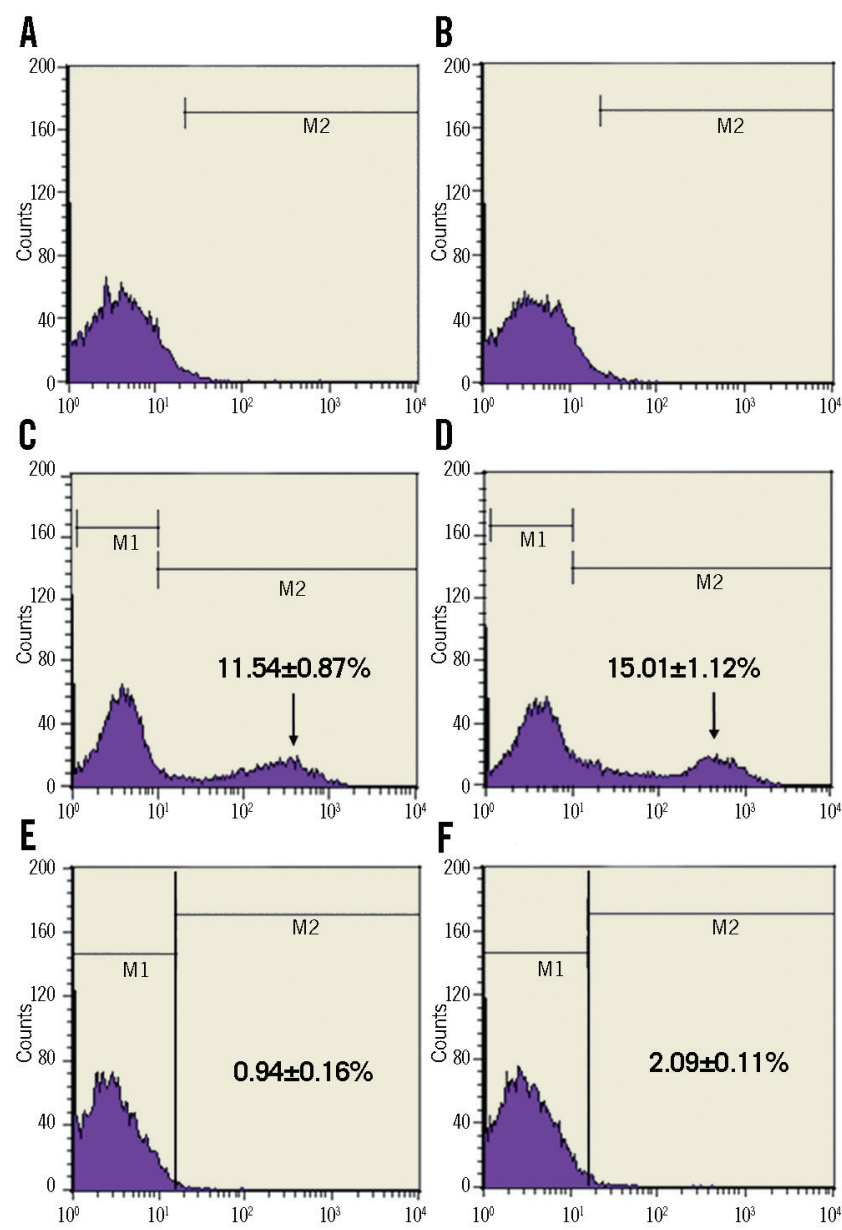

Figure 1. Flow cytometry analysis of hTEC. Flow cytometry analysis of hTEC with FITC labelled anti-porcine $\operatorname{Ig} G$ and IgM antibodies showing hTEC+anti-IgG:FITC (A) and hTEC+anti-IgM:FITC (B). Porcine PBMC+anti-IgG:FITC $(C)$ and porcine PBMC+antiIgM:FITC (D). hTEC+anti-IgG:FITC $+50 \%$ porcine serum $(E)$ and +anti-IgM:FITC+50\% porcine serum $(F)$.

implantation or at 28 days (Table 1). IVUS assessment at day 28 also showed no difference in minimal stent area or minimal lumen area between the two groups (Table 1). Histological examination of these sections revealed a variable amount of neointimal tissue

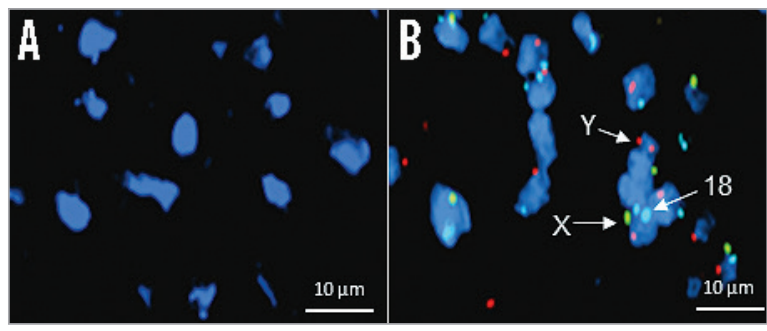

Figure 2. Fate of hTEC after stent implantation. Fluorescent micrographs of neointimal tissue at 28 days from hTEC (XY) seeded stents in female (XX) pigs. A) Early passage hTEC for comparison. $B)$ The X chromosome was detected by green, the Y chromosome by red and the 18 chromosome by aquamarine fluorescence. 


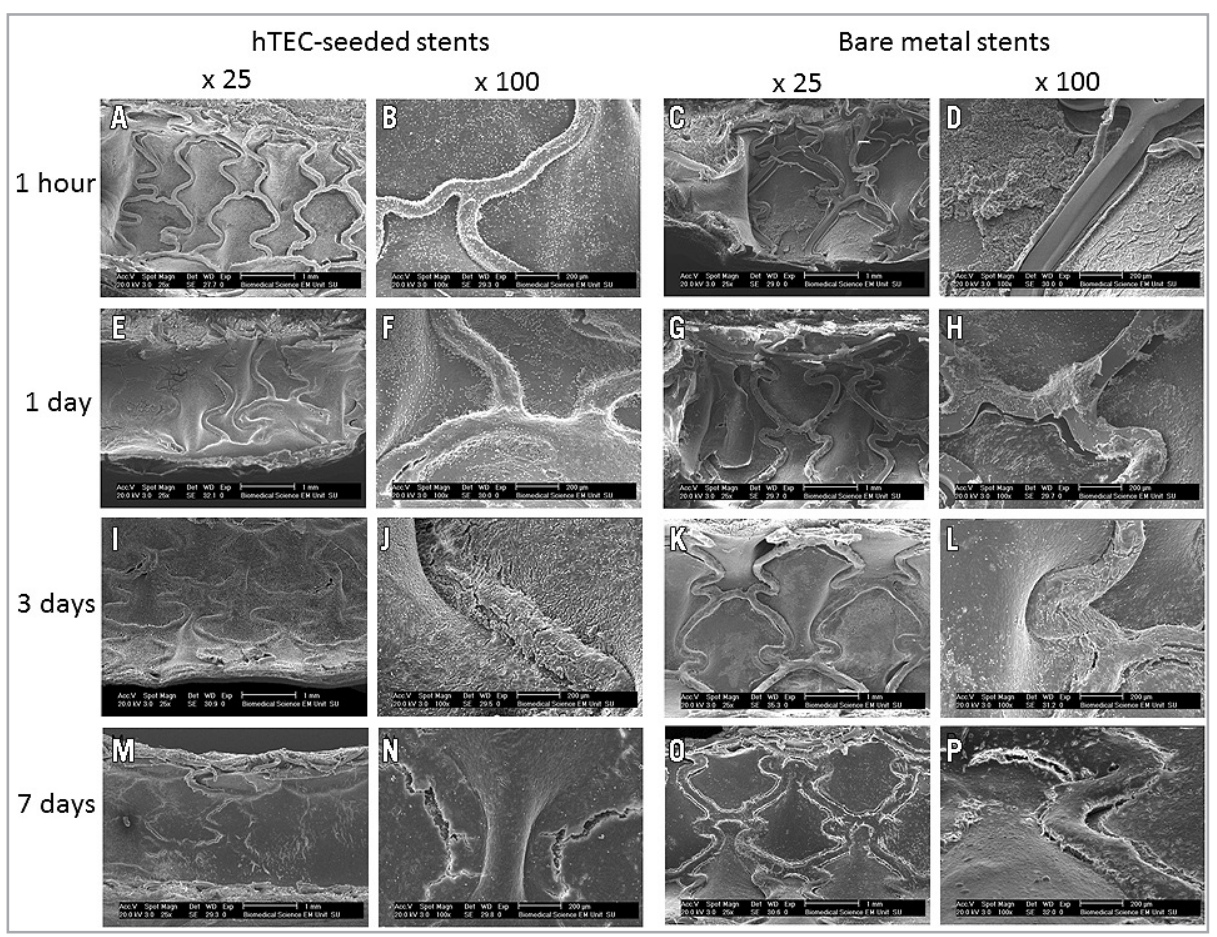

Figure 3. Scanning electron microscopy for assessment of strut coverage. Representative images from scanning electron microscopy of BMS and $h T E C$-seeded stents under low $(\times 25)$ and high $(\times 100)$ magnification at one $h r(h T E C$-seeded [A,B]; BMS [C,D]), one day (hTEC-seeded [E,F]; BMS [G,H]), three days (hTEC-seeded [I,J]; BMS: [K,L]) and seven days (hTEC-seeded [M,N]; BMS [O,P]) after stent implantation.

growth, in keeping with vascular injury that ranged from mild to severe (Figure 5). Histomorphometric examination of 120 analysable sections from 10 pairs of BMS and hTEC-seeded stents showed

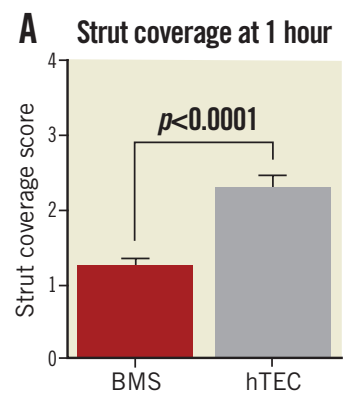

C Strut coverage at 3 days

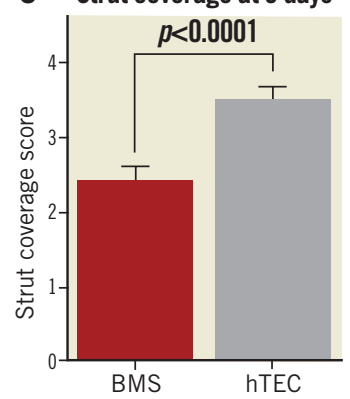

\section{B Strut coverage at 1 day}

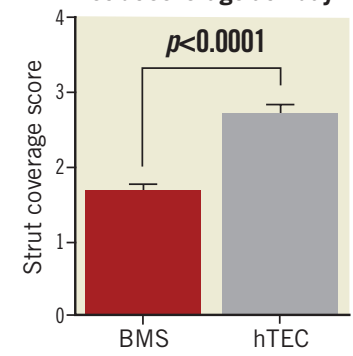

D Strut coverage at 7 days

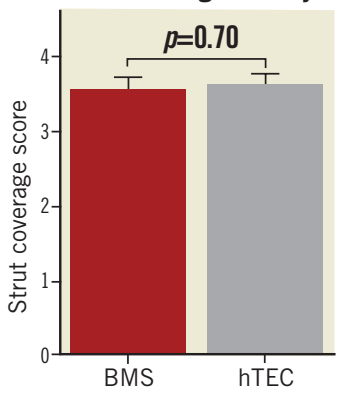

Figure 4. Stent strut coverage of bare metal and hTEC-seeded stents. Stent strut coverage of BMS compared to hTEC-seeded stents at one hr (A), one day (B), three days (C) and seven days (D) after stent implantation. This demonstrates earlier strut coverage in hTECseeded stents.
Table 1. Vessel measurements using quantitative coronary angiography (QCA) and intravascular ultrasound (IVUS).

\begin{tabular}{|l|c|c|c|}
\hline QCA & BMS & hTEC stent & $\boldsymbol{p}$-value \\
\hline Reference vessel diameter (mm) & $\mathbf{n = 1 0}$ & $\mathbf{n}=10$ & \\
\hline $\begin{array}{l}\text { Minimal lumen diameter post } \\
\text { implantation (mm) }\end{array}$ & $2.78 \pm 0.01$ & $2.79 \pm 0.01$ & 0.83 \\
\hline Minimal lumen diameter at day 28 (mm) & $2.23 \pm 0.10$ & $2.11 \pm 0.20$ & 0.61 \\
\hline Diameter stenosis (\%) & $36.20 \pm 4.14$ & $45.40 \pm 6.82$ & 0.26 \\
\hline Late lumen loss (mm) & $1.17 \pm 0.15$ & $1.23 \pm 0.18$ & 0.80 \\
\hline IVUS at day 28 & $\mathbf{n = 9 *}$ & $\mathbf{n}=\mathbf{g}^{*}$ & \\
\hline Minimal stent area (mm²) & $7.68 \pm 0.23$ & $7.48 \pm 0.13$ & 0.45 \\
\hline Minimal lumen area (mm²) & $5.09 \pm 0.28$ & $5.04 \pm 0.37$ & 0.92 \\
\hline Minimal stent diameter (mm) & $3.12 \pm 0.05$ & $3.09 \pm 0.03$ & 0.47 \\
\hline Minimal lumen diameter (mm) & $2.54 \pm 0.07$ & $2.52 \pm 0.09$ & 0.88 \\
\hline $\begin{array}{l}\text { *IVUS measurements could not be obtained in one } \mathrm{hTEC} \text {-seeded stent so stent pair excluded } \\
\text { from analysis. BMS: bare metal stents; hTEC: human trophoblastic endovascular progenitor cells }\end{array}$ \\
\hline
\end{tabular}

that the vessel size and Schwartz injury score were similar between the groups receiving BMS and the hTEC-seeded stents (Figure 6). The lumen and neointimal area were also similar between the two groups (Figure 6).

\section{Discussion}

Our study has demonstrated the feasibility and safety of a novel approach to accelerate stent healing in the coronary artery, by implanting metal stents pre-coated with stem cells of human 


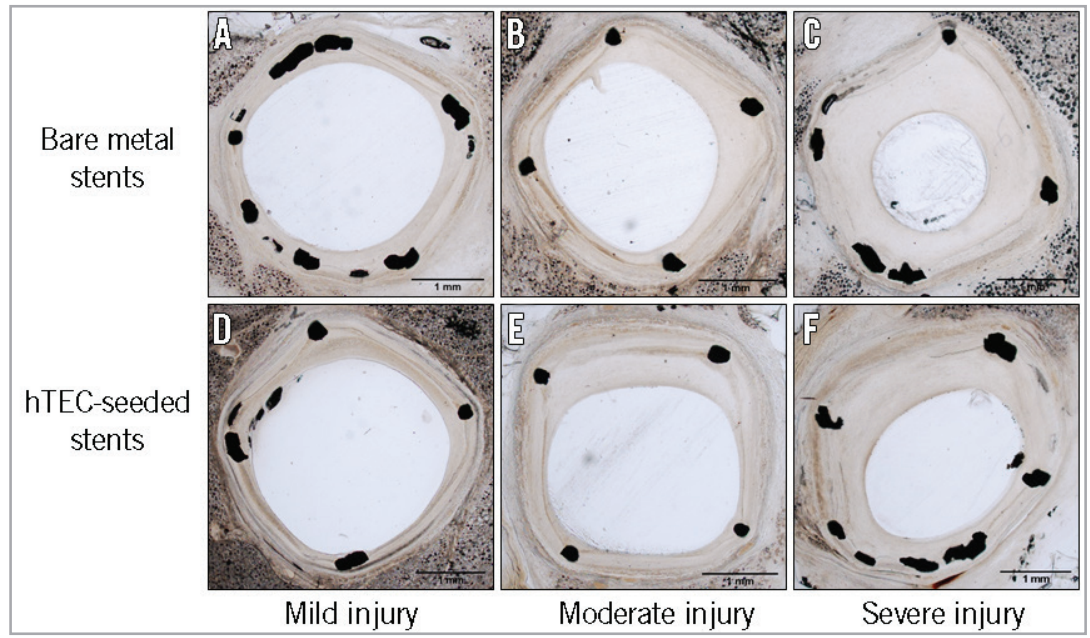

Figure 5. Tissue response to stent implantation at 28 days. Representative light microscopy images of sections from the BMS group: A) mild injury, B) moderate injury, C) severe injury; and from the hTEC-seeded group: D) mild injury, E) moderate injury, F) severe injury.

embryonic trophoblastic endovascular progenitor cells. In our study, the hTEC-seeded stents showed earlier stent strut coverage, without excessive neointimal proliferation, compared to BMS.

There was a series of major challenges to achieve this outcome in our study. First, the animal experiments were, perhaps, even more stringent than will be seen in clinical trials, because there was the potential for immune-mediated cell rejection by testing human cells in pigs. However, because of the "immune protection" afforded by expression of HLA-G in the cells, there was hardly any binding of
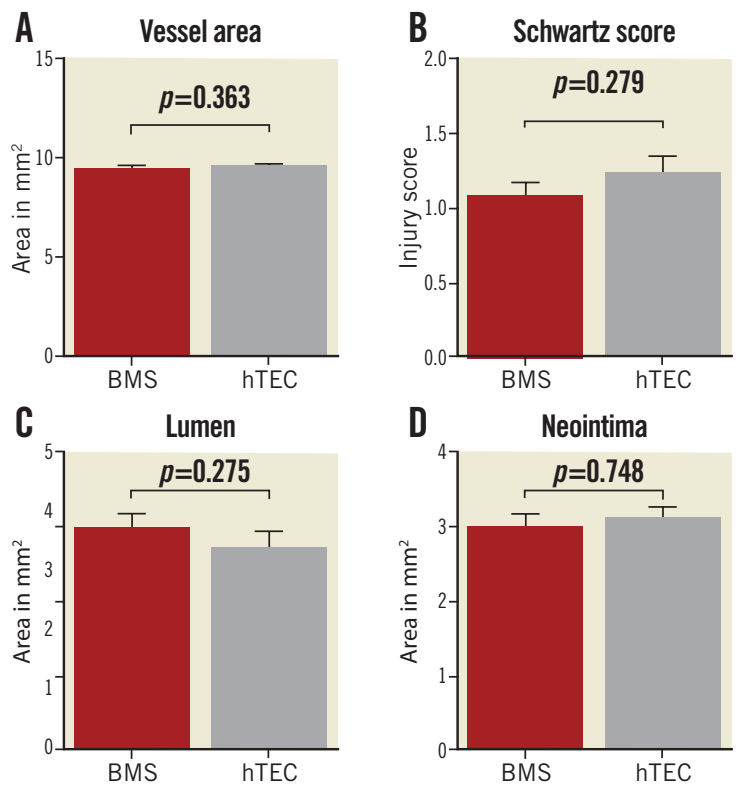

Figure 6. Histomorphometric outcome of bare metal and hTECseeded stents. Histomorphometric measurements of tissue sections at 28 days after stent implantation (mean \pm SEM). Total vessel area $(A)$, Schwartz injury score (B), lumen (C) and neointimal area (D). This demonstrates no difference in injury score, vessel area, lumen area and neointimal proliferation between the two groups.
hTEC to pre-existing porcine anti-human IgG and IgM antibodies. Second, the cells were required to adhere to the stent surface. We demonstrated that this was possible in cell culture. Third, it was important to demonstrate cell survival after stent implantation. We showed that a sizeable proportion of seeded cells remained at the implantation site, with little or no detection elsewhere, using radioactive labelling. Finally, we showed accelerated coverage of stent struts at early time points, together with neutrality of neointimal growth at 28 days, compared with BMS.

The alternative technique, of attracting coverage of endogenous circulating endothelial progenitor cells (EPC), has gained limited success $^{24}$. Stents loaded with anti-CD34 antibodies (Genous ${ }^{\mathrm{TM}}$; OrbusNeich Medical Technologies, Fort Lauderdale, FL, USA) have shown good healing response at the price of restenosis, which is greater than that seen in first-generation DES ${ }^{16}$. The TRIAS HR (TRI-stent adjudication study-high risk of restenosis) trial comparing the Genous ${ }^{\mathrm{TM}}$ EPC capture stent with DES had to be terminated early due to excess restenosis in the EPC capture stent-treated patients ${ }^{17}$. This technology is dependent upon the capacity of the patient to mobilise endothelial precursors. Yet patients with severe coronary artery disease have fewer EPCs with reduced migratory potential and lower functional capacity ${ }^{25,26}$. The number of circulating EPCs in peripheral blood in all subjects is extremely low. A study estimated early CD133+ / CD34+ / VEGFR-2+ cells in healthy human subjects to be $0.002 \%$ of the total PBMC with a reported increase in the number to $0.02 \%$ of the total PBMC after stimulation with granulocyte colony stimulating factor (G-CSF) ${ }^{27}$. Moreover, a homing response of EPCs has not been confirmed after PCI performed for acute coronary syndromes ${ }^{28}$. The advantage of pre-seeding stents with stem cells is that no reservoir or mobilisation of circulating and functional EPCs capable of homing to the site of vascular injury is required.

Our findings are positive compared with previously attempted cell-seeding stents. Seeding with endothelial cells has been shown to increase neointimal proliferation in a rabbit model ${ }^{29}$. Mesenchymal 
stem cell seeding has been shown to promote endothelialisation and inhibits the neointimal hyperplasia compared with BMS in a rabbit model, but no subsequent studies have been conducted in large animals or in $\operatorname{man}^{30}$. It is encouraging that we achieved accelerated healing without excessive neointimal growth at a late time point. Stents coated with hTEC may be clinically useful in patients with high bleeding risk, planned surgery or anticipated problems with prolonged dual antiplatelet therapy. One possibility might be to coat stents with hTEC on the luminal aspect and an antiproliferative drug on the abluminal, to achieve accelerated coverage with reduced neointimal proliferation. Further studies of this novel device are warranted.

\section{Limitations}

This study has several limitations. The porcine coronary stenting model lacks atherosclerosis and relies upon the de novo growth of neointima due to vascular injury caused by stent implantation in a disease-free artery. Additionally, results from juvenile healthy animals may not be directly extrapolated to ageing human patients with comorbidities. Characterisation of the progenitor cell phenotype is challenging. The hTEC used in our study possessed a mixed progenitor and mature endothelial phenotype, expressing both progenitor and mature endothelial markers, but surface marker patterns remain controversial.

\section{Conclusion}

This study has demonstrated the safety and feasibility of implanting a novel intracoronary stent seeded with hTEC in a large animal model. This approach can accelerate tissue regeneration over the stent struts without provoking excessive neointimal growth.

\section{Impact on daily practice}

This is a preclinical study in a clinically relevant large animal model demonstrating a novel approach to enhance stent strut coverage by coating stents with human trophoblastic endovascular progenitor cells. Further studies are warranted before this technology can be used in clinical practice.

\section{Acknowledgements}

We are grateful to the Department of Trade and Industry, UK, for funding this study and to D. Baker at the Sheffield Children's Hospital for performing cytogenetic analysis of the porcine neointimal tissue samples.

\section{Conflict of interest statement}

The authors have no conflicts of interest to declare.

\section{References}

1. Task Force on Myocardial Revascularization of the European Society of Cardiology (ESC) and the European Association for Cardio-Thoracic Surgery (EACTS); European Association for Percutaneous Cardiovascular Interventions (EAPCI), Wijns W,
Kolh P, Danchin N, Di Mario C, Falk V, Folliguet T, Garg S, Huber K, James S, Knuuti J, Lopez-Sendon J, Marco J, Menicanti L, Ostojic M, Piepoli MF, Pirlet C, Pomar JL, Reifart N, Ribichini FL, Schalij MJ, Sergeant P, Serruys PW, Silber S, Sousa Uva M, Taggart D. Guidelines on myocardial revascularization. Eur Heart J. 2010;31:2501-55.

2. Iqbal J, Serruys PW, Taggart DP. Optimal revascularization for complex coronary artery disease. Nat Rev Cardiol. 2013;10: 635-47.

3. Serruys PW, Strauss BH, Beatt KJ, Bertrand ME, Puel J, Rickards AF, Meier B, Goy JJ, Vogt P, Kappenberger L, et al. Angiographic follow-up after placement of a self-expanding coronary-artery stent. $N$ Engl J Med. 1991;324:13-7.

4. Morice MC, Serruys PW, Sousa JE, Fajadet J, Ban Hayashi E, Perin M, Colombo A, Schuler G, Barragan P, Guagliumi G, Molnar F, Falotico R; RAVEL Study Group. A randomized comparison of a sirolimus-eluting stent with a standard stent for coronary revascularization. $N$ Engl J Med. 2002;346:1773-80.

5. Stone GW, Ellis SG, Cox DA, Hermiller J, O'Shaughnessy C, Mann JT, Turco M, Caputo R, Bergin P, Greenberg J, Popma JJ, Russell ME; TAXUS-IV Investigators. A polymer-based, paclitaxel-eluting stent in patients with coronary artery disease. $N$ Engl J Med. 2004;350:221-31.

6. Daemen J, Wenaweser P, Tsuchida K, Abrecht L, Vaina S, Morger C, Kukreja N, Juni P, Sianos G, Hellige G, van Domburg RT, Hess OM, Boersma E, Meier B, Windecker S, Serruys PW. Early and late coronary stent thrombosis of sirolimus-eluting and paclitaxel-eluting stents in routine clinical practice: data from a large two-institutional cohort study. Lancet. 2007;369:667-78.

7. Lagerqvist B, James SK, Stenestrand U, Lindback J, Nilsson T, Wallentin L. Long-term outcomes with drug-eluting stents versus bare-metal stents in Sweden. $N$ Engl J Med. 2007;356: 1009-19.

8. Iqbal J, Sumaya W, Tatman V, Parviz Y, Morton AC, Grech ED, Campbell S, Storey RF, Gunn J. Incidence and predictors of stent thrombosis: a single-centre study of 5,833 consecutive patients undergoing coronary artery stenting. EuroIntervention. 2013;9:62-9.

9. Iakovou I, Schmidt T, Bonizzoni E, Ge L, Sangiorgi GM, Stankovic G, Airoldi F, Chieffo A, Montorfano M, Carlino M, Michev I, Corvaja N, Briguori C, Gerckens U, Grube E, Colombo A. Incidence, predictors, and outcome of thrombosis after successful implantation of drug-eluting stents. JAMA. 2005; 293:2126-30.

10. Burzotta F, Parma A, Pristipino C, Manzoli A, Belloni F, Sardella G, Rigattieri S, Danesi A, Mazzarotto P, Summaria F, Romagnoli E, Prati F, Trani C, Crea F. Angiographic and clinical outcome of invasively managed patients with thrombosed coronary bare metal or drug-eluting stents: the OPTIMIST study. Eur Heart J. 2008;29:3011-21.

11. Iqbal J, Gunn J, Serruys PW. Coronary stents: historical development, current status and future directions. Br Med Bull. 2013;106:193-211. 
12. Virmani R, Guagliumi G, Farb A, Musumeci G, Grieco N, Motta T, Mihalcsik L, Tespili M, Valsecchi O, Kolodgie FD. Localized hypersensitivity and late coronary thrombosis secondary to a sirolimus-eluting stent: should we be cautious? Circulation. 2004;109:701-5.

13. Joner M, Finn AV, Farb A, Mont EK, Kolodgie FD, Ladich E, Kutys R, Skorija K, Gold HK, Virmani R. Pathology of drug-eluting stents in humans: delayed healing and late thrombotic risk. $J \mathrm{Am}$ Coll Cardiol. 2006;48:193-202.

14. Aoki J, Serruys PW, van Beusekom H, Ong AT, McFadden EP, Sianos G, van der Giessen WJ, Regar E, de Feyter PJ, Davis HR, Rowland S, Kutryk MJ. Endothelial progenitor cell capture by stents coated with antibody against CD34: the healing-FIM (healthy endothelial accelerated lining inhibits neointimal growth-first in man) registry. J Am Coll Cardiol. 2005;45:1574-9.

15. Low AF, Lee CH, Teo SG, Chan MY, Tay E, Lee YP, Chong E, Co M, Tin Hay E, Lim YT, Tan HC. Effectiveness and safety of the genous endothelial progenitor cell-capture stent in acute ST-elevation myocardial infarction. Am J Cardiol. 2011;108:202-5.

16. Beijk MA, Klomp M, Verouden NJ, van Geloven N, Koch KT, Henriques JP, Baan J, Vis MM, Scheunhage E, Piek JJ, Tijssen JG, de Winter RJ. Genous endothelial progenitor cell capturing stent vs. the Taxus Liberte stent in patients with de novo coronary lesions with a high-risk of coronary restenosis: a randomized, single-centre, pilot study. Eur Heart J. 2010;31:1055-64.

17. Klomp M, Beijk MA, Varma C, Koolen JJ, Teiger E, Richardt G, Bea F, van Geloven N, Verouden NJ, Chan YK, Woudstra P, Damman P, Tijssen JG, de Winter RJ. 1-year outcome of TRIAS HR (TRI-stent adjudication study-high risk of restenosis) a multicenter, randomized trial comparing genous endothelial progenitor cell capturing stents with drug-eluting stents. JACC Cardiovasc Interv. 2011;4:896-904.

18. Garg S, Duckers HJ, Serruys PW. Endothelial progenitor cell capture stents: will this technology find its niche in contemporary practice? Eur Heart J. 2010;31:1032-5.

19. Harun R, Ruban L, Matin M, Draper J, Jenkins NM, Liew GC, Andrews PW, Li TC, Laird SM, Moore HD. Cytotrophoblast stem cell lines derived from human embryonic stem cells and their capacity to mimic invasive implantation events. Hum Reprod. 2006;21:1349-58.

20. Udayashankar R, Baker D, Tuckerman E, Laird S, Li TC, Moore HD. Characterization of invasive trophoblasts generated from human embryonic stem cells. Hum Reprod. 2011;26: 398-406.
21. Aflatoonian B, Ruban L, Shamsuddin S, Baker D, Andrews P, Moore H. Generation of Sheffield (Shef) human embryonic stem cell lines using a microdrop culture system. In Vitro Cell Dev Biol Anim. 2010;46:236-41.

22. Malik N, Gunn J, Holt CM, Shepherd L, Francis SE, Newman CM, Crossman DC, Cumberland DC. Intravascular stents: a new technique for tissue processing for histology, immunohistochemistry, and transmission electron microscopy. Heart. 1998;80:509-16.

23. Schwartz RS, Huber KC, Murphy JG, Edwards WD, Camrud AR, Vlietstra RE, Holmes DR. Restenosis and the proportional neointimal response to coronary artery injury: results in a porcine model. J Am Coll Cardiol. 1992;19:267-74.

24. Swanson N, Hogrefe K, Javed Q, Malik N, Gershlick AH. Vascular endothelial growth factor (VEGF)-eluting stents: in vivo effects on thrombosis, endothelialization and intimal hyperplasia. J Invasive Cardiol. 2003;15:688-92.

25. Vasa M, Fichtlscherer S, Aicher A, Adler K, Urbich C, Martin H, Zeiher AM, Dimmeler S. Number and migratory activity of circulating endothelial progenitor cells inversely correlate with risk factors for coronary artery disease. Circ Res. 2001;89:E1-7.

26. Hill JM, Zalos G, Halcox JP, Schenke WH, Waclawiw MA, Quyyumi AA, Finkel T. Circulating endothelial progenitor cells, vascular function, and cardiovascular risk. $N$ Engl J Med. 2003; 348:593-600.

27. Peichev M, Naiyer AJ, Pereira D, Zhu Z, Lane WJ, Williams M, Oz MC, Hicklin DJ, Witte L, Moore MA, Rafii S. Expression of VEGFR-2 and AC133 by circulating human CD34(+) cells identifies a population of functional endothelial precursors. Blood. 2000;95:952-8

28. Banerjee S, Brilakis E, Zhang S, Roesle M, Lindsey J, Philips B, Blewett CG, Terada LS. Endothelial progenitor cell mobilization after percutaneous coronary intervention. Atherosclerosis. 2006;189:70-5.

29. Arts CH, De Groot PG, Attevelt N, Heijnen-Snyder GJ, Verhagen HJ, Eikelboom BC, Blankensteijn JD. In vivo transluminal microvascular endothelial cell seeding on balloon injured rabbit arteries. J Cardiovasc Surg (Torino). 2004;45:129-37.

30. Wu X, Wang G, Tang C, Zhang D, Li Z, Du D, Zhang Z. Mesenchymal stem cell seeding promotes reendothelialization of the endovascular stent. J Biomed Mater Res A. 2011;98:442-9.

\section{Online data supplement}

Appendix. Methods. 


\section{Online data supplement}

\section{Appendix. Methods \\ PREPARATION OF hTEC STEM CELLS}

hTEC were derived by the terminal differentiation of trophoblast stem cells while the latter were derived as distinct trophoblast cell lines (TS) from human embryonic stem cells (Shef 3 and six cell lines). A vial of TS cells $\left(2 \times 10^{6}\right.$ cells $\left./ \mathrm{ml}\right)$ was recovered from longterm storage in liquid nitrogen and thawed into Dulbecco's Modified Eagle Medium (DMEM) supplemented with 10\% foetal calf serum (FCS), washed by centrifugation $(\times 2)$ and cultured in $2 \times \mathrm{T} 25$ culture flasks with fresh medium at $37^{\circ} \mathrm{C}$ in $5 \% \mathrm{CO}_{2}$ in air for 10 days. During this time, the cells terminally differentiated to a proven endovascular phenotype, and further cell proliferation was arrested.

\section{ISOLATION OF PORCINE ENDOTHELIAL AND SMOOTH MUSCLE CELLS}

Endothelial and smooth muscle cells were isolated from porcine thoracic aortae. Porcine aortic endothelial cells (PAoEC) were cultured in DMEM supplemented with $2.5 \mu \mathrm{g} / \mathrm{mL}$ amphotericin $\mathrm{B}, 100 \mathrm{U} / \mathrm{mL}$ of penicillin and streptomycin, $2 \mathrm{mM}$ L-glutamine, $20 \mu \mathrm{g} / \mathrm{mL}$ of endothelial cell growth supplement, $90 \mu \mathrm{g} / \mathrm{mL}$ of heparin and $20 \%$ porcine serum, and incubated at $37^{\circ} \mathrm{C}$ in $5 \% \mathrm{CO}_{2}$ in air. Porcine vascular smooth muscle cells (PVSMC) were cultured in DMEM supplemented with $2.5 \mu \mathrm{g} / \mathrm{mL}$ amphotericin $\mathrm{B}$, $100 \mathrm{U} / \mathrm{mL}$ penicillin and streptomycin, $2 \mathrm{mM}$ L-glutamine, $1 \times$ nonessential amino acids and $20 \%$ porcine serum, and incubated at $37^{\circ} \mathrm{C}$ in $5 \% \mathrm{CO}_{2}$ in air. Both PAoECs and PVSMCs adhered to the bottom of gelatine-coated tissue culture flasks and once confluent were passaged using $0.1 \%$ trypsin and $0.02 \%$ ethylenediaminetetraacetic acid (EDTA). Fixed PAoEC were stained for endothelial cell markers; E-selectin and von Willebrand Factor (vWF). For E-selectin staining, PAoEC were stimulated with recombinant human tumour necrosis factor-alpha (hTNF- $\alpha$; AbD Serotec, Kidlington, Oxford, UK) prior to methanol fixation. Staining of fixed PVSMC was carried out for $\alpha$-smooth muscle actin ( $\alpha$-SMA) and smooth muscle myosin heavy chain (SM-MHC).

\section{PORCINE ANTIBODIES AGAINST hTEC}

The effect of any pre-existing circulating anti-human porcine antibodies upon hTEC was determined by exposing hTEC to porcine serum followed by flow cytometry analysis with FITC labelled anti-porcine IgG and IgM antibodies. hTEC $\left(1 \times 10^{5}\right)$ were incubated with increasing dilutions of porcine serum $(50 \%, 20 \%, 10 \%$, $5 \%$ and $2 \%$ ) and treated with anti-pig IgG or IgM: FITC antibody (AHP865F and AAI39F; AbD Serotec) and $2 \%$ goat serum at $4^{\circ} \mathrm{C}$. The samples were centrifuged at $500 \mathrm{~g}$ for five minutes, supernatant aspirated and a fluorescence activated cell sorting (FACS) analysis of the resulting cell suspension performed using a FAC Scan (Becton Dickinson, Oxford, UK) analyser. Viability of samples was confirmed by propidium iodide staining. Untreated hTEC and hTEC incubated with only anti-pig IgG and IgM antibodies were used as negative controls. Mononuclear cells isolated from freshly obtained whole blood were used as positive controls. 